\title{
Strategies of global recession for small business enterprises in emerging markets: Case of South Africa
}

\author{
Louise van Scheers \\ Department of Marketing and Retail \\ University of South Africa
}

\author{
Key words \\ Strategies of Global Recession SMEs; Reducing costs strategies; increasing growth strategies
}

\begin{abstract}
.
The aim of this chapter was to examine strategies of global recession for SMEs in emerging markets such as South Africa. A recession is considered as one of the most crucial environmental threats to SMEs' viability, profitability and survival. Sensitive SMEs may close down, and many decrease their production capacity due to insufficient consumer demand which is a cause of global recession. Secondary examination of references indicates that it seems that South African SMEs in times of recession uses reducing costs and increasing growth strategies to survive global recessions. Luckily, SMEs have flexible managerial structures and therefore can adapt their strategies in times of recessions to survive.
\end{abstract}

Corresponding author: Louise van Scheers

Email addresses for corresponding author: vscheml@unisa.ac.za

First submission received: 23rd April 2017

Revised submission received: 1oth August 2017

Accepted: 31st August 2017

\section{Introduction}

A recession is considered as one of the most crucial environmental threats to small business enterprises' (SMEs) viability, profitability and sustainability (Pearce and Byars, 2012). Recession is a phenomenon of decreasing demand for raw materials, products and services. SMEs are also influenced in different ways by economic crises. Sensitive SMEs may close down, and many decrease their production capacity due to insufficient consumer demand. Ntsika (2012) observes that input prices of raw material increase which mean higher input costs which consequently increases prices of products. Pearce and Byars (2012) explain that specifically in a recession SMEs need to reduce operational costs and improve efficiency to be competitive. The recent global economic crisis did not economical influenced only large companies, but because of their size also SMEs (Nieman, Hough and Niewenhuizen, 2012 and Alstete, 2014). The economic recession affects SMEs marketing strategies decisions as well as consumers' perceptions and behaviours. The marketing function of SMEs plays a vital role to assist them to survive as SMEs need to stay profitable and consumer responsive even more so in recessions. Therefore, the global recession creates challenges which contribute to the failure of SMEs also in South Africa. It seems that SMEs have little flexibility to cope with decreasing demand, scarcer financing and delayed payments. The research examines strategies of global recession for SMEs in emerging markets such as South Africa. The research will assist SME managers to formulate strategies to fight the global recession.

\section{Research methodology}

Secondary sources were used to gather information and to construct a literature review for this chapter because secondary data is the cheapest and easiest means of gathering information. The main sources of secondary sources were journals, articles, press reports, books, and research studies.

\section{Literature review}

Defining Small Business Enterprises in Emerging Markets: Case of South Africa

It is difficult to formulate a universal definition of a small business enterprise because the economies of countries differ, and people adopt particular standards for particular purposes. Secondary research [Bowler, Dawood \& Page (2014) Phakisa (2013)] indicated that there are no universally accepted small business definitions. What is regarded in the US as a small business by definition would often be 
regarded as a medium sized business elsewhere in the world. Small business definitions differ vastly in smaller countries like New Zealand and South Africa to their bigger counterparts in the US and the EU. In South Africa Phakisa (2013) defines an enterprise with less than 100 employees as a SME. Small business undertakings create about 80 percent of all new job opportunities and according to Bowler, Dawood \& Page (2014) more than 70 percent of all South Africans are employed in the small business sector. The small business sector is an essential factor in promoting and achieving economic growth and development and the widespread creation of wealth and employment. Nager, Swanepoel and van der Merwe, (2008: 37) indicated that small business development should be an essential component of all reconstruction and development initiatives and this has the potential to economically empower the majority of the country's people. However, secondary resources revealed that 40 percent of new business ventures fail in their first year, 60 percent in their second year, and 90 percent in their first 10 years of existence (Pearce \& Byars, 2012).

\section{Overview of SMEs}

It is universally recognised that SMEs play an important role in helping to diversify a country's economic base by providing it with opportunities to respond to varying local market conditions (Bennet, 2009; Browser, 2013 and Boyd and Larreche, 2014). In today's age SMEs adoption of Internet technologies is vital for their on-going survival in an increasingly competitive marketplace locally and globally. Porter (2009) explains that the motive for this is that the Internet offers direct links with trading customers and suppliers by facilitating information transfer which brings with it certain efficiencies. Hallberg (2014) regards SMEs as an important economic performance accelerator of a country because they make up most of the businesses and employment. They have huge potential for innovation which is a value added to the economic wellbeing of a country. SMEs are highly focussed at high product quality, responsiveness to consumer needs and flexibility. To stay competitive with large scale enterprises. SMEs around the world contribute significantly to job creation and the national economy. 90 percent of the number of businesses in the United States is run by families. These family businesses employ half of the USAs workforce (2008) which produced half of the United States gross national product. It is also worth to mention that in this nation 78 percent of all new jobs are employed by family businesses (McCann et al, 2008).

The European SMEs' impact on the European economy as various recent studies has demonstrated that SMEs on average account for $50 \%$ for the Gross Domestic Product (GDP) in these highincome countries. In the OECD (Organisation for Economic Co-operation and Development) countries 75 percent of the formal workforce is employed by SMEs. In the EU-27 in 2008 on average 57.9 percent of the SMEs added to the GDP and accounted for over 67 percent of the employment. Between 2002 and 2008 SMEs grew employment by an average of 1, 9 percent per year in contrast with the large-scale enterprises which grew only with 0.8 percent per year.

\section{A Global view of SMEs}

SMEs are defined differently across the world. Definitions are usually based per country on the number of employees in the SME, the number of sales or gross profit or the total of assets the SME holds. According to a report by Dalberg (2011) in Egypt a SME is defined as having more than 5 and less than 50 employees. Compared to another developing country for example Vietnam where they consider a SME to have between 10 and 300 employees. Delving onto the developed countries the Inter-American Development bank defines SMEs as having a maximum of 100 employees and fewer than $\$ 3$ million in revenue per year. Comparing this to the European definition of SMEs to have less than 250 employees and in the United States is set at less than 500 employees per SME (Natarajan \& Wyrick, 2011).

Here below follows a table presenting SME definitions by multilateral institutions.

\begin{tabular}{|c|c|c|c|}
\hline Institution & $\begin{array}{l}\text { Maximum \# of } \\
\text { Employees }\end{array}$ & $\begin{array}{l}\text { Max. Revenues or } \\
\text { Turnover (US \$) }\end{array}$ & Maximum Assets (US \$) \\
\hline World Bank & 300 & 15000000 & 15000000 \\
\hline MIF - IADB & 100 & 3000000 & (none) \\
\hline $\begin{array}{l}\text { African Development } \\
\text { Bank }\end{array}$ & 50 & (none) & (none) \\
\hline
\end{tabular}

www.jbrmr.com A Journal of the Academy of Business and Retail Management (ABRM) 


\begin{tabular}{|lllc|}
\hline $\begin{array}{l}\text { Asian } \\
\text { Bank }\end{array}$ & Development & No official definition. & Uses only individual national governmental definitions. \\
\hline UNDP & 200 & (none) & (none) \\
\hline
\end{tabular}

Table 1:SME definitions used by multilateral institutions in the world

Source: Natarajan \& Wyrick, 2011

As shown in table 1 there is substantial variance in how these institutions define the characteristics of SMEs in the world. For example, take the World Bank Group. It includes businesses three times larger by employees and five times larger by turnover or assets than the largest SME under the Multilateral Investment Fund (MIF) as can be seen in the table here above. When taking into consideration that the developing members countries of the World bank average gross national income per capita (PC-GNI) is significantly smaller in value than the average PC-GNI for the countries of Latin America and the Caribbean server by the MIF. No explanations exist for the differences in defining SMEs articulated by these institutions (Tom, 2008). Within the same context, we should consider the official definitions of SMEs in a group of economically and geographically diverse set of countries. Table 2 below shows the group listed by each country's rank in the PC-CNI and the second table next to it ranked to the maximum employment of an SME as stated by their national government.

\begin{tabular}{|l|l|l|l|l|}
\hline $\begin{array}{l}\text { Country ranked by } \\
\text { PC-GNI }\end{array}$ & Max. \# Employees & $\begin{array}{l}\text { Country ranked by SME } \\
\text { Size }\end{array}$ & Max. \# Employees \\
\hline Norway & 100 & & Vietnam & 300 \\
\hline Switzerland & 250 & & Belarus & 250 \\
\hline Australia & 200 & & Moldova & 250 \\
\hline Brazil & 100 & & Switzerland & 250 \\
\hline Belarus & 250 & & Australia & 200 \\
\hline Thailand & 200 & Morocco & 200 \\
\hline Peru & 200 & Peru & 200 \\
\hline Moldova & 250 & Thailand & 200 \\
\hline Morocco & 200 & & Bangladesh & 100 \\
\hline Egypt & 50 & & Brazil & 100 \\
\hline Nicaragua & 100 & & Ghana & 100 \\
\hline Pakistan & 50 & & Nicaragua & 100 \\
\hline Vietnam & 300 & & Norway & 100 \\
\hline Bangladesh & 100 & & Malawi & 50 \\
\hline Ghana & 100 & & Pakistan & 50 \\
\hline Tanzania & 20 & & Tanzania & 50 \\
\hline Malawi & 50 & 20 \\
\hline
\end{tabular}

Table 2:Official National Definitions of SMEs ranked by PC-CNI and their maximum number of employees

Source: Natarajan \& Wyrick, 2011

Considering the table above, it is peculiar that the largest SME is three times the size of an SME in Norway, whereby logically one would expect a wealthier economy would have larger size businesses relative to other businesses in the country. In particular looking at PC-GNI, a SME in Egypt is half the size in employees in comparison to Ghana, although Egypt's PC-GNI is roughly three times larger than Ghana's (Tom et al. 2008). A recent study Oxford Economics (2013) has shown that SMEs across the BRICS countries are acting on international scale, competing with ever larger rivals. They are investing into technology to improve operations and become more agile. Overall the findings are showing a strong transformation that is changing the global markets for companies of all sizes and bringing the newest innovations to the forefront.

The SMEs in the BRICS countries in the study strongly agree that global competition has substantially increased in the last two years. SMEs are increasingly focused on penetrating new geographical markets. At least two thirds of the SMEs are now competing against larger companies than in the past. (Oxford Economics, 2013). Emerging markets are considered as Brazil, Chile, China, Colombia, Czech Republic, Hungary, India, Mexico, Russia, and South Africa. South Africa is part of 
the BRICS countries, but how are SMEs seen in the South African context? In the next section the SME will be shown in South African context.

\section{SMEs in the South African context}

SMEs are defined in different ways, with reference to the number of employees or to turnover bands (as in the National Small Business Act 1996, which also allows for variations according to industry sector). In South Africa, a 'small business' is official defined in Section 1 of the National Small Business Act of 1996 as amended by the National Small Business Amendment Acts of 2003 and 2004 (NSB Act) as a separate and distinct business entity, including co-operative enterprises and nongovernmental organisations, managed by one owner or more which, including its branches or subsidiaries, if any, is predominantly carried on in any sector or sub-sector of the economy (National Small Business Act of 1996).

The NSB Act also categories small businesses in SA into distinct groups, namely; survivalist, micro, very small, small and medium, hence the use of the term "SMME" for small, medium and microenterprises. However, the terms 'SMME' and 'SME' are used interchangeably in SA. The SME definition uses the number of employees (the most common mode of definition) per enterprise size category combined with the annual turnover categories, the gross assets excluding fixed property. The National Small Business Act (Act 102 of 1996) provides definitions for various SMME categories as identified in Table 3.

\begin{tabular}{|c|c|c|c|}
\hline Enterprise Size & Number of employees & Annual turnover & $\begin{array}{c}\text { Gross assets, excluding } \\
\text { fixed property }\end{array}$ \\
\hline Medium & $\begin{array}{c}\text { Fewer than } 100 \text { to 200, } \\
\text { depending on industry }\end{array}$ & $\begin{array}{c}\text { Less than R4 million to R50 million, } \\
\text { depending upon industry }\end{array}$ & $\begin{array}{c}\text { Less than R2 million to } \\
\text { R18 million, depending } \\
\text { on industry }\end{array}$ \\
\hline Small & Fewer than 50 & $\begin{array}{c}\text { Less than R2 million to R25 million, } \\
\text { depending on industry }\end{array}$ & $\begin{array}{c}\text { Less than R2 million to } \\
\text { R4,5 million, depending } \\
\text { on industry }\end{array}$ \\
\hline Very small & $\begin{array}{c}\text { Fewer than } 10 \text { to 20, } \\
\text { depending on industry }\end{array}$ & $\begin{array}{c}\text { Less than R200 000 to R500 000, } \\
\text { depending on Industry }\end{array}$ & $\begin{array}{c}\text { Less than R150 000 to } \\
\text { R500 000, depending on } \\
\text { industry }\end{array}$ \\
\hline Micro & Fewer than 5 & Less than R150 000 & Less than R100 000 \\
\hline
\end{tabular}

Table 3: Definitions of SMEs given in the National Small Business Act.

Source: Dockel, J. A. and Ligthelm, A. A. (2012) Factors that contribute to small business survival. Article submitted for publication. Pretoria: Unisa

The most widely used framework in South Africa is the definition of the National Small Business Act, which defines five categories of business as follows:

Survivalist enterprise: The income generated is less than the minimum income standard or the poverty line. This category is considered pre-entrepreneurial, and includes hawkers, vendors and subsistence farmers. (In practice, survivalist enterprises are often categorised as part of the micro-enterprise sector.)

Micro enterprise: The turnover is less than the VAT registration limit (that is, R150 000 per year). These enterprises usually lack formality in terms of registration. They include, for example, spaza shops, minibus taxis and household industries. They employ no more than five people.

Very small enterprise: These are enterprises employing fewer than 10 paid employees, except mining, electricity, manufacturing and construction sectors, in which the figure is 20 employees. These enterprises operate in the formal market and have access to technology.

Small enterprise: The upper limit is 50 employees. Small enterprises are generally more established than very small enterprises and exhibit more complex business practices.

Medium enterprise: The maximum number of employees is 100, or 200 for the mining, electricity, manufacturing and construction sectors. These enterprises are often characterised by the decentralisation of power to an additional management layer.

The promotion and development of SMEs in South Africa is currently the focus of much attention in a wide variety of fields because it is regarded as a major key to economic development and wealth creation, thereby contributing towards social prosperity and upward mobility. The demand for an entrepreneurial - driven economy in South Africa is increasing particularly because of the employment 
creation benefits it offers. The SME sector is globally regarded as the driving force in economic growth and job creation (Lunsche and Barron, 2010).

\section{Impact of global recession on SMEs}

The impact of recession on SMEs can be viewed from vulnerability and resilience views as Driver, Wood, Segal and Herrington, (2011) point out. SMEs are vulnerable because of external factors in their business environment such as changes technology, politics, and government legislation on which the SME has no control over (Goldstuck, 2012). The resilience view stresses that SMEs are flexible because of their size and their ability to take quick managerial decisions. SMEs can quickly adjust resources and processes to survive in difficult economic times such as global recessions. The global recession is creating threats to small businesses, but luckily their flexibility and small size are assisting them to survive. However, it has compelled SMEs to rethink their business strategies. I study done by Hin, Kadir and Bohari (2014) indicate that SMEs after a global recession use a combination of corporate strategies which include the following integration strategy, product development, as well as stability and defensive strategy.

\section{Marketing Strategies for South African SMEs}

Research shows that the failure rate among small businesses is high, although in most cases many such failures could have been avoided if SMEs give attention to developing appropriate marketing strategies. Downie (2012) states that an often reiterated "fact-that eight out of every ten start-ups in South Africa fail. Poor marketing strategies have been cited by various researchers as one of the reasons for SME failure. According to Mabaso (2008) and Brink, Can't \& Ligthelm (2003:1) the failure rate of small, medium and micro enterprises SME's is estimated to be between 70 and 80 per cent. Brink, et al. (2003:1) goes further to state that often the ideas are good and the people behind them are capable, but that they have no idea about how to run a business and develop marketing strategies. The concept of marketing strategy refers to the unique and differentiable positioning of the enterprise's towards its customer's needs. In order for this to be the case the firm would have to clearly understand the environment within which it operates, know the client and competitor's strengths and weaknesses well, and tactically align its own resources and capabilities to meet client's needs profitably. This approach to strategy is symptomatic of the views expressed by Redsicker (2014), where they track the origins of marking strategy back to warfare. In the words of General Karl von Clausewitz, also referred to by Redsicker (2014) as one of the world's greatest marketing strategist', the celebrated German army General says that:

'War belongs to the province of business competition, which is also a conflict of human interests and activities.

Clausewitz was first to assert that war (and marketing) is based on two immutable characteristics: strategy and tactics. This articulation of marketing goes beyond the traditional definition of marketing as provided by Hussaina, Si and Wang (2013). 'Marketing strategy is a process of identifying customer needs, conceptualising those needs in terms of an organisation's capacity to produce, communicating that conceptualisation to the appropriate laws of power in the organisation, conceptualising the consequent output in terms of the customer needs earlier identified, and communicating that conceptualisation to the customer.'

The fault line with the above stated definition of marketing in Redsicker (2014) opinion is that it assumes that the organisation with the best marketing research capability will win the marketing war. This marketing philosophy is based on a singular notion of customer focus. An obsession of which becomes problematic particularly when every company becomes customer-oriented and seeks to serve the same customer needs. In this scenario (scenario where every company seeks to serve the same customer needs) the race for marketing becomes a defeatist one-prize-race, where there can only be one winner. The 'winner' is often the biggest (in terms of size and resources) in the 'race' or industry, has traditional or historic claims to the crown, and barring any major deviations shall forever remain in pole-position. According to McCue (2009) marketing strategy is a method of focusing an organization's energies and resources on a course of action which can lead to increased sales and dominance of a targeted market niche. A marketing strategy combines product development, promotion, distribution, pricing, relationship management and other elements; identifies the firm's marketing goals, and explains how they will be achieved, ideally within a stated timeframe. Marketing strategy determines the choice of target market segments, positioning, marketing mix, and allocation of resources. It is most effective when it is an 
integral component of overall firm strategy, defining how the organization will successfully engage customers, prospects, and competitors in the market arena.

According to different researchers such as van Scheers and Radipere (2007:1) and Parson (2010) it is evident that small business owners lack certain managerial skills such as financial management and marketing and human managerial skills to operate their businesses successfully. The research of van Scheers and Radipere (2007:1) confirm that SME owners are in need of support services and that they are constrained by financial as well as non-financial factors such as lack of education, inadequate technical skills, poor access to markets, lack of information and reliable infrastructure. The research established that the lack of managerial skills has negative impact on the success and viability of small businesses. According to McCue (2009) marketing strategy is a method of focusing an organization's energies and resources on a course of action which can lead to increased sales and dominance of a targeted market niche and increase the viability of the SME. A marketing strategy combines product development, promotion, distribution, pricing, relationship management and other elements; identifies the firm's marketing goals, and explains how they will be achieved, ideally within a stated timeframe. Marketing strategy determines the choice of target market segments, positioning, marketing mix, and allocation of resources. It is most effective when it is an integral component of overall firm strategy, defining how the organization will successfully engage customers, prospects, and competitors in the market arena.

As the customer constitutes the source of a company's revenue, marketing strategy is closely linked with sales. A key component of marketing strategy is often to keep marketing in line with a company's overarching mission statement (McCue, 2009). According to Taiwo (2010) to achieve a set organizational goals and objectives, companies conceptualized, design, and implement various strategies. These strategies can be corporate, business, or functional. Marketing strategies constitute one of the functional strategies amenable to application by contemporary companies in order to enhance performance. Nerurkar (2014) explains that a marketing strategy has been a salient focus of academic inquiry since the 1980s. There are numerous definitions of marketing strategy in the literature and such definitions reflect different perspectives. However, the consensus is that marketing strategy provides the avenue for utilizing the resources of an organization in order to achieve its set goals and objectives. Generally, marketing strategy deals with the adapting of marketing mix elements to environmental forces. It evolves from the interplay of the marketing mix elements and the environmental factors.

According to Naude and Havenga (2014) the aim of the development of an organization's marketing strategy development is to establish, build, defend and maintain its competitive advantage. Mutula and Van Brakel (2010) observe that the benefit of having a good marketing strategy for SMEs is important. The first advantage it gives in an entity is to make it known to the consumer if a product is available. The SME owners can never stop to promote and market their product or service to the consumer and that one advantage of marketing strategies is to increase sales and revenue. When the consumer knows about the product if it was marketed correctly, customers will be motivated to buy it.

\section{Creating a Marketing Strategy}

Marketing strategy planning means to find attractive opportunities and develop profitable marketing strategies. A marketing strategy specifies a target market and a related marketing mix. A marketing mix has four major points: The four P's, Product, Place, Promotion, and Price shown in Figure 1

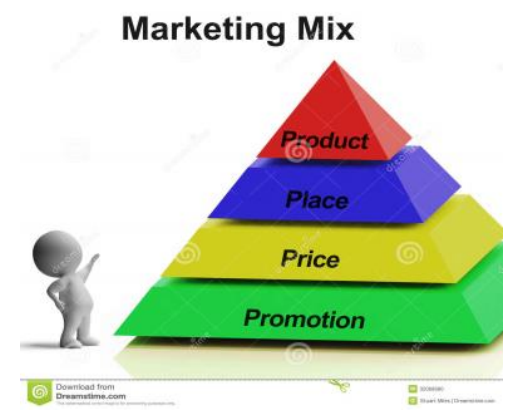

Figure 1: $\quad$ Marketing Mix 
As indicated in figure 1, the customer is placed in the centre of the four Ps because the customer should be the focal point of all marketing efforts and really all business efforts. Without potential customers--and eventually satisfied customers--there is not much point in any company effort. Almost any product, for example ball point pens or sports shirts, might be used to illustrate the way that products can and should be designed with the customer in mind, made conveniently available, promoted to these potential customers, and priced attractively or competitively--again with the customer in mind. The interrelatedness of the decisions (as shaped by the needs and attitudes of the various potential customers) illustrates the innovative approach to marketing strategy. Kotler (2012) take the dimensions of marketing strategy innovation further as they look at the new marketing concepts for times of economic recessions, as tabled below.

\begin{tabular}{|l|l|}
\hline Conventional marketing strategy & The new Marketing strategy \\
\hline Organize by product units & Organize by customer segments \\
\hline Focus on profitable transactions & Focus on customer lifetime value \\
\hline Judge performance primarily by financial results & Look at marketing metrics as well as financial ones \\
\hline Focus on satisfying shareholders & Focus on satisfying several stakeholder groups \\
\hline The marketing department does the marketing & Everyone in the company does marketing \\
\hline Build brands primarily through advertising & Build brands through company behaviour \\
\hline Emphasize customer acquisition & Emphasize customer retention \\
\hline Measure customer satisfaction & Measure customer value and loyalty \\
\hline Over-promise to get the order & Under-promise to over deliver \\
\hline Make the firm the unit of analysis & Make the value chain the unit of analysis \\
\hline
\end{tabular}

Table 4: Dimensions of Innovation

Source: Kotler, P. (2012). 'Kellogg on Marketing'

Table 1 shows the new approach to creating a marketing strategy. An important point mentioned is that everyone in the company should do marketing.

Market share defence in times of recessions

The impact of globalisation and Internet technology has made it difficult and increasingly complex to predict where the next competitor will surface especially in times of recessions. The speed by which new players can enter a market is also increasing day by day, making it ever so difficult to speak of a static market share. These changes have made the traditional concept of market share hollow. The type of marketing strategy explored earlier revolves around notions of business concept innovation, the customer's total economic equation, and a militarist approach to competitive strategy. This view redefines the notion of markets in its suggestion that a set number of players must converge at a single summit of a single mountain. Marketing strategies, in time of recession, thrives on creating new summits, redefining 'the market' as something bigger than just a place for product/service competition but rather an individual economic customer. Marketing strategy formulation is a powerful process that gives an organization a competitive advantage in the marketplace. While just defining a marketing, strategy will not automatically create a competitive advantage, it will allow the organization to concentrate its (always limited) resources on the greatest opportunities to increase sales and achieve a sustainable competitive advantage. The word strategy comes from the Greek word strategos meaning general. Strategy is what generals use to win battles. Thus, properly understood, marketing strategy is a high-level exercise involving the "generals" of the organization in determining how to build on the firm's strengths while (ethically) taking advantage of competitors' weaknesses? Marketing strategy is most effective when it is a vital component of corporate strategy, defining how the organization will engage customers, prospects and the competition in the market arena for consistent success. In implementing a marketing strategy various change situation may occur. The achievement of the objectives of successfully implementing a market strategy leads to organisational effectiveness in the short term but it can inhibit necessary change in the long term. SME owners should be responsive to change in a dynamic post-recession business 
environment. For example, Nikon when it was confronted with technological changes such as digital cameras it quickly created a new digital camera. SMEs just as Nikon need to be adaptable and change it marketing strategy whenever it is needed. Luckily, SMEs have flexible management structures which could change rapidly so that the SME can survive global recessions.

\section{Competitive Strategies in times of recessions}

Competitive strategies can be defined as the basis for much of modern business strategy and form an important strategy in times of global recession. Strategy for SMEs is to know where the SME is today, where the SME owner wants to take it, how the SME owner is going to get there. Competitive Strategy as per Porter, firstly look at the five competitive forces which determine the rules of competition (Porter, 2014) the entry of new competitors, 2) the threat of substitutes, 3) the bargaining power of buyers, 4) the bargaining power of suppliers, and 5) the rivalry among the existing competitors.

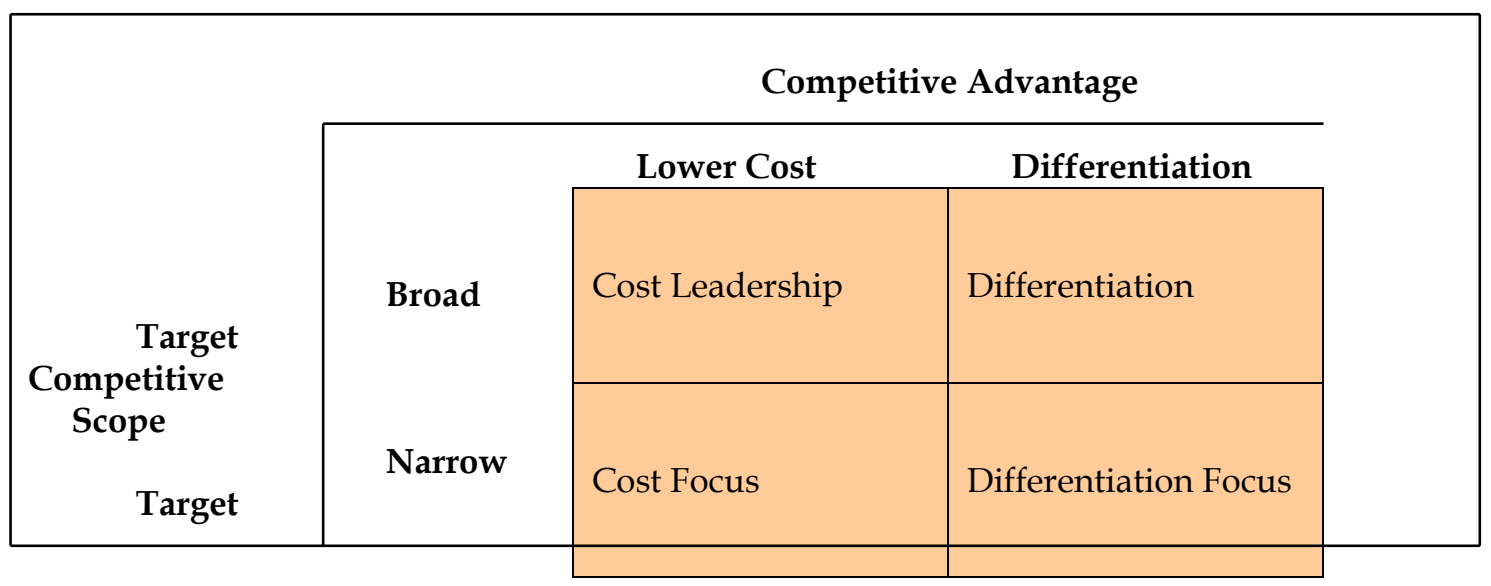

Figure 2: $\quad$ Porter's Generic Strategies

Source: Adapted from Porter, M.E, 2014

Secondly (see Figure 2), Porter then argues that competitive strategy involves the leveraging of the company's strengths by either cost advantage or differentiation over competitors; as can be found in Porter's Generic Strategies (Porter, 2014). Cost leadership targets broad markets whereby you need to be producing at costs lower than the average market and Cost Focus just has a narrow segment strategy. Differentiation strategy calls for the product or service to have unique attributes that are valued by customers and perceived to be better than the rest of the market whilst Differentiation Focus just has a narrow market strategy approach. All of these strategies are employed in order to gain an advantage over competitors for increased market growth.

Gopal (2012) show, from their survey of small UK businesses during recession, that many exhibit resilience, flexibility, adaptability and absorptive capacity underpinned by personal sacrifices of the owners: "survival, almost regardless of personal cost, is instinctive". SMEs survival strategies in times of recessions can be grouped into two groups, namely: reducing costs and increasing growth. The reducing cost strategy includes downsizing the workforce, reducing products and reducing stock whereas growth strategies include offering new or improved products and competing on price as observed by Xia and Tang (2011); Mohamad and Ching (2008).

\section{Conclusion}

The aim of this chapter was to examine strategies of global recession for SMEs in emerging markets such as South Africa. It seems that South African SMEs in times of recession uses reducing costs and increasing growth strategies to survive global recessions. Luckily, SMEs have flexible managerial structures and therefore can adapt their strategies in times of recessions to survive. Future research can be based on exploring global strategies for SMEs in emerging markets such as South Africa in prosperous times. 


\section{References}

Act No. 102 of 1996. NATIONAL SMALL BUSINESS ACT. 1996 as amended by the National Small Business Amendment Acts of 2003 and 2004 (NSB Act)

Alstete, JW. 2014. On becoming an entrepreneur: an evolving typology. International Journal of Entrepreneurial Behaviour \& Research, Vol. 8 No.4, 2002, p 222 - 234.

Baldwin, A., Lymer, A. and Johnson, R. 2013. "Business Impacts of the Internet for Small and Mediumsized Enterprises," E-Commerce and V-Business: Business Mode.

Bennet, K. 2009 www.cabdirect.org/abstracts/20123332465.

Bowler A, Dawood MS, Page S (2007). Entrepreneurship and Small Business Management. Pretoria: Juta and Co. Ltd.

Boyd W, Larreche M (2014). Marketing Management: A Strategic Decision-Making employees New York: McGraw Hill.

Browser in www.polity.org.za/article/sa-statement-by-statistics-south-africa-general-household-survey2013-18062014-2014-06-18-1.

Carter, M. 2011. Small but nimble. SME marketing. Vol. 3 Iss: 2, pp.33 - 48

Ceglie, G. and Dini, M. (2005): SME Cluster and Network Development in Developing Countries: The Experience of UNIDO, UNIDO.

Dalberg 2011 in European Investment Bank, 2011. “EIB Policy towards weakly regulated, non-transparent and uncooperative jurisdictions"

Deakins, D. 2006 Entrepreneurship and small firms. McGraw-Hill, London. Developed and Transition Economies: A Reader. Ashgate Publishing Limited:

Dockel, J. A. and Ligthelm, A. A. (2012) Factors that contribute to small business survival. Article submitted for publication. Pretoria: Unisa.

Downie 2012 in www.rogerdownie.com/2012/welcome-to-small-business-month/

Driver, A. Wood, E. Segal, N. and Herrington, M. 2011. Global Entrepreneurship

DTI (Department of Trade and Industry) Accessed on date at www.thedti.gov.za (12/ 03/ 2007).

Goldstuck, A. 2012. Internet matters: the quiet engine of the South African economy. [Online] Available from: [Downloaded: 2013-07-01].

Gopal, G. 2012. Challenges in sourcing and procurement during an economic downturn: A case study of an Indian automotive parts supplier. Business \& Entrepreneurship Journal, 1(1), 13-29

Hallberg, D. 2005 in http://www.actacommercii.co.za/index.php/acta/

Hin, CW, Kadir, KA and Abdul Manaf Bohari,AM. 2014. Hybrid Strategy and Competitive Strategy: Evidence from Northern States SMEs in Malaysia. Asian Journal of business \& Management Sciences. Vol 3 No 10.

Hussaina, I., Si, S. and Wang, L. 2013. Comparative study on internal and external CFFs on SMES. Journal of Small business and Entrepreneurship. Volume 23, Issue 4.

Kotler, P. 2012, Marketing an introduction. Pearson Prentice-Hall, London, London. ISBN 9780273762607.

Luiz, J. 2002. "Small Business Development, Entrepreneurship and Expanding the Business Sector in a Developing Economy: The case of South Africa." The Journal of Applied Business Research. Vol. 18, No.2.

Mohamad, H.M \& Ching, I.S. (2008). Variations in Performances in Chinese Small and Medium Enterprises. Malaysian Management Review, 43(2), 87-109.

McCann, T. 2008 in OECD (2008), ICT, e-business and SMEs, OECD Publications, Paris.

McCue, T. 2009 in OECD (2009), ICT, e-business and SMEs, OECD Publications, Paris.

Monitor 2011 Executive Report. Graduate School of Business. University of Cape Town.

Natarajan, G. S. and Wyrick, D. A. 2011. Proceedings of the World Congress on Engineering 2011 Vol I WCE 2011, July 6 - 8, 2011, London, U.K.

Naude, W.A and Havenga, J.J.D. 2014. An Overview of African Entrepreneurship and Small Business Research. Journal of Small Business and Entrepreneurship 18, No. 1. pp:101-120.

Nerurkar, J. 2014 in Moore and S.L. Manring, K. "Strategy Development in Small and Medium Sized Enterprises for Sustainability and Increased Value Creation," Journal of Cleaner Production, vol. 17, pp. 276-282, 2014. 
Nieman, G., Hough, J. and Niewenhuizen, C. 2012. Entrepreneurship: A South African perspective. Pretoria: Van Schaik, Pretoria.

Ntsika. 2012. State of Small Business in South Africa: Annual Review. Ntsika Enterprise Promotion Agency. Pretoria.

OECD (2004), ICT, e-business and SMEs, OECD Publications, Paris.

Orford, J., Wood, E., Fischer, C., Herrington, M. and Segal, N. 2008. Global Entrepreneurship Monitor: South African Executive Report 2003. Cape Town: Graduate School of Business, University of Cape Town.

Oxford Economics Report. 2013. http://www.fitzroy.cl/wp-content/uploads/2013/05/Travel-andTourism-Competitiveness-2013-Fuente-WEF.pdf

Parson, K. 2010 in http://www.fitzroy.cl/wp-content/uploads/2010/05/Travel-and-TourismCompetitiveness-2010-Fuente-WEF.pdf.

Pearce, J. and Byars, D. 2012. The Tenuous Link Between Formal Strategic Planning and Financial Performance. Academy of Management. http:// amr.aom.org/content/12/4/658.short

Phakisa, J. in Van Scheers, L. 2011 SMEs' marketing skills challenges in South Africa. http:/ / uir.unisa.ac.za/handle/10500/6526. [Accessed:].

Porter, M. 2014 in http:/ / www.sciencedirect.com/science/article/pii/ S0883902604000047.

Redsicker, T. 2014 in http://www.fitzroy.cl/wp-content/uploads/2014/05/Travel-and-TourismCompetitiveness-2014-Fuente-WEF.pdf

TDI (The Department of Trade and Industry) report 2012. www.dyi.org.

Van Scheers, L. 2011. SME marketing skills challenges in South Africa. African Journal of Business Management, 2011-07.

Xia, Y., \& Tang, T. L.-P. (2011). Sustainability in supply chain management: suggestions for

the auto industry. Management Decision, 49 (4), 495 - 512.

(www.treasury.gov.za).

http://www.niu.edu/ lynch/mixed_methods.pdf

(http://www.southalabama.edu/coe/bset/johnson/

http://www.southalabama.edu/)

http://cybertimes.in/?q=node/490

http://web.b.ebscohost.com/abstract 